American Journal of Environmental Sciences 5 (5): 664-668, 2009

ISSN 1553-345X

(C) 2009 Science Publications

\title{
Production of Potassium and Calcium Hydroxide, Compost and Humic Acid from Sago (Metroxylon sagu) Waste
}

\author{
${ }^{1}$ C.P. Auldry, ${ }^{1}$ O.H. Ahmed, ${ }^{2}$ A.M. Nik Muhamad, ${ }^{3}$ H. Mohammad Nasir and ${ }^{1}$ M. Jiwan \\ ${ }^{1}$ Department of Crop Science, Faculty of Agriculture and Food Sciences, \\ University Putra Malaysia Bintulu Sarawak Campus, 97008 Bintulu, Sarawak \\ ${ }^{2}$ Department of Forest Management, Faculty of Forestry, \\ University Putra Malaysia, 43400 Serdang, Selangor, Malaysia \\ ${ }^{3}$ Department of Animal Science and Fishery, Faculty of Agriculture and Food Sciences, \\ University Putra Malaysia Bintulu Sarawak Campus, 97008 Bintulu, Sarawak
}

\begin{abstract}
Problem statement: Agriculture waste such as Sago Waste (SW) has a potential to cause pollution when the waste is discarded into rivers. In order to add value to SW, a study was conducted to produce potassium and calcium hydroxide, compost and Humic Acid (HA) from SW. Approach: The SW was air-dried and some grinded. The grinded SW was incinerated at $600^{\circ} \mathrm{C}$. Potassium and calcium hydroxide was extracted by dissolving the ash in distilled water at a ratio of 1:500 (ash: water), equilibrated for $24 \mathrm{~h}$ at $150 \mathrm{rpm}$ using a mechanical shaker and filtered. The ungrinded SW was used for compost production. The compost was produced by mixing SW $(80 \%)+$ chicken feed $(10 \%)$ + chicken dung slurry $(5 \%)+$ molasses $(5 \%)$. Results: The hydroxide extracted from ash of SW was used to isolate $\mathrm{HA}$ of composted SW. The molarity and $\mathrm{pH}$ of the hydroxide were $0.002 \mathrm{M}$ and 10 respectively. Calcium $\left(42.88 \mathrm{mg} \mathrm{kg}^{-1}\right)$ and potassium $\left(29.51 \mathrm{mg} \mathrm{kg}^{-1}\right)$ content were high in the hydroxide compared with other elements. The compost took about 60 days to mature. There was an increased in $\mathrm{pH}$, ash, Cation Exchange Capacity (CEC) and HA and a decreased in temperature, $\mathrm{C} / \mathrm{N}$ ratio, $\mathrm{C} / \mathrm{P}$ ratio and organic matter. The hydroxide was able to extract $1 \%$ of $\mathrm{HA}$ from the composted SW. A comparison between the yields of HA extracted from the composted SW using the hydroxide of the SW and that of the analytical grade showed no statistically difference. The chemical characteristics of HA from the composted SW were in standard range. Conclusion: Potassium and calcium hydroxide, compost and HA can be produced from sago waste. Low morality of the hydroxide is able to produce good quality of HA from composted sago waste. The HA can be reconstituted with K and $\mathrm{Ca}$ from potassium and calcium hydroxide to produce $\mathrm{K}$-Ca-humate and this needs to be investigated as a form of organic based fertilizer.
\end{abstract}

Key words: Sago Waste (SW), Humic Acids (HA), hydroxide, compost

\section{INTRODUCTION}

It is estimated that about 60 million tonnes of sago starch, extracted from sago palms, are produced per annum in south-east $\mathrm{Asia}^{[1]}$. Most of the factories are built near riversides where Sago Waste (SW) is likely to be discarded into rivers, a practice which may cause water pollution. The amount of waste (fiber and water) from sago is about 20 times the total starch production and this large quantity of waste causes problems to sago starch processing units ${ }^{[2]}$. In addition, inefficient starch extraction contributes to waste and large amounts of potentially polluting waste materials ${ }^{[3]}$. For every
$100 \mathrm{~kg}$ of starch in pith (of 70-90 kg can be extracted), there will be $10 \mathrm{~kg}$ of hampas. This quantity may be greater if the extraction efficiency is low and about $5 \mathrm{~kg}$ of fermentable dissolved solids-mostly sugars and protein $^{[4]}$, additional, $60-70 \%$ of starch can create high BOD and COD levels in the river ${ }^{[5]}$. The microbiology activities in the river consume a lot of oxygen to degrade the waste and this may results in insufficient oxygen for aquatic healthy life ${ }^{[4]}$.

Some researchers have used SW as substrate for cultivation of edible mushrooms ${ }^{[2]}$, animal feed, production of enzymes ${ }^{[6]}$ and absorbents ${ }^{[7]}$. SW also can be used for composting where the matured compost can

Corresponding Author: Osumanu Haruna Ahmed, Department of Crop Science, Faculty of Agriculture and Food Sciences, University Putra Malaysia Bintulu Campus, Sarawak, Malaysia Tel: +6086855406 Fax: +6086855415 
be treated as organic fertilizer. According to Cambardella et al. ${ }^{[8]}$, nutrient uptake of plants can be improved by applying compost to soils. Besides applying the compost directly to the soil, Humic Acids (HA) can also be extracted from the compost whereby the HA can be reconstituted with $\mathrm{K}$ from $\mathrm{KOH}$ to produce $\mathrm{K}$-humate which can be used for fertigation and for fresh water fishes ${ }^{[9]}$. The usage of inorganic fertilizer as well as waste production can be reduced through composting $^{[10]}$. The HA from the compost can become the backbone and carrier of minerals which can stimulate the absorption of the minerals to the plant. In order to add value to SW, a study was conducted to produce potassium and calcium hydroxide, compost and HA from it.

\section{MATERIALS AND METHODS}

The SW was collected from Nit Sei in Mukah, Sarawak. The SW was air-dried and some of it was grinded for the purpose of initial characterization and ashing. The ungrinded SW was used for compost production. Grinded sago waste was incinerated at 300 , $350,400,450,500,550$ and $600^{\circ} \mathrm{C}$ using a muffle furnace. The best ash (almost white) was chosen for potassium and calcium hydroxide production. The ash was dissolved in distilled water at ratios of 1:100, $1: 200,1: 300,1: 400$ and 1:500. The samples were equilibrated for $24 \mathrm{~h}$ at $150 \mathrm{rpm}$ using a mechanical shaker. Afterwards, the samples were filtered using Whatman filter paper number 2. The ratio of 1:500 was chosen because its hydroxides had the highest morality of $0.002 \mathrm{M}(\mathrm{pH} 10)$. The $0.002 \mathrm{M}$ of the hydroxide obtained from the ash was analyzed for $\mathrm{K}, \mathrm{Ca}, \mathrm{Mg}, \mathrm{Na}$, $\mathrm{Fe}, \mathrm{Zn}, \mathrm{Cu}$ and $\mathrm{Mn}$ using Atomic Absorption Spectrophotometry (AAS).

The composting process was done inside a white polystyrene box with a size of $61.5 \times 49 \times 33.5 \mathrm{~cm}$. The compost was produced by mixing SW $(80 \%)+$ chicken feed $(10 \%)+$ chicken dung slurry $(5 \%)+$ molasses (5\%). The ambient and compost temperatures were taken daily (morning and evening). The temperature of the compost was monitored until it equaled ambient temperature after which it was analyzed for $\mathrm{pH}$, total nitrogen, organic carbon, organic matter, ash, Cation Exchange Capacity (CEC), phosphorus and HA using standard procedures. Moisture content of the compost ranged between $50-70 \%{ }^{[11]}$ and turning was done once a week.

The HA was isolated by the method of Stevenson $^{[12]}$ but with some modifications. The compost and the hydroxide $(0.002 \mathrm{M})$ (extracted from the ash of SW) was placed inside a polyethylene bottle in a ratio of 1:10 (weight: Volume basis). The mixture was shaken at $240 \mathrm{rpm}$ for $24 \mathrm{~h}$ at room temperature. Afterwards, the mixture was centrifuged for $15 \mathrm{~min}$ at $10,000 \mathrm{rpm}$. The dark-colored supernatant liquid containing HA was decanted, filtered using Whatman filter paper number $2, \mathrm{pH}$ of the liquid was adjusted to 1.0 using $6 \mathrm{~N} \mathrm{HCl}$ and allowed to stand at room temperature for $24 \mathrm{~h}$. The suspension containing HA was transferred into polyethylene bottle and centrifuged at $10,000 \mathrm{rpm}$ for $10 \mathrm{~min}$. The HA was purified by the method of Ahmed et al. ${ }^{[13]}$, by using distilled water and through centrifugation at $10,000 \mathrm{rpm}$ for $10 \mathrm{~min}$ to reduce mineral matter and $\mathrm{HCl}$ during acidification ${ }^{[14]}$. After the purification, the HA was oven dried at $40^{\circ} \mathrm{C}$ until constant weight was attained.

The ash and organic carbon contents of the HA were determined by the dry combustion method ${ }^{[15]}$. For the functional groups analysis, $20 \mathrm{mg}$ of HA was dissolved in $4 \mathrm{~mL}$ of $0.08 \mathrm{M} \mathrm{NaOH}$ and shaken for $30 \mathrm{~min}$ at $180 \mathrm{rpm}$. The solution was titrated with 0.10 $\mathrm{M} \mathrm{HCl}$ to $\mathrm{pH} 2.5$ (within $15 \mathrm{~min}$ ). Carboxyl content was calculated based on the amount of acid required to titrate the suspension between $\mathrm{pH} 8$ and the end point (approximately $\mathrm{pH} 3$ ). Phenol content was calculated by assuming that $50 \%$ of the phenols dissociated at $\mathrm{pH} 10$. Total acidity was calculated by summation of the carboxyl and phenols ${ }^{[16]} \cdot \mathrm{E}_{4} / \mathrm{E}_{6}$ determined by the method of Campitelli and Ceppi ${ }^{[17]}$ and analyzed using UV-Vis spectrophotometer (Perkin-Elmer Lambda 11).

The yields of the HA (from composted SW) extracted with the hydroxide of SW and that of analytical grade $(\mathrm{KOH})$ were compared using independent T-test. Statistical Analysis System (SAS Ver. 9.1) was used for the statistical analysis.

\section{RESULTS}

The liquid obtained from the ashed SW was high in $\mathrm{K}$ and $\mathrm{Ca}$ but very low in $\mathrm{Zn}, \mathrm{Cu}$ and $\mathrm{Mn}$ (Table 1). The highest content of macroelement was $\mathrm{Ca}(42.88 \mathrm{mg}$ $\mathrm{kg}^{-1}$ ) and followed by $\mathrm{K}\left(29.51 \mathrm{mg} \mathrm{kg}^{-1}\right)$, Na and $\mathrm{Mg}$. The microelements such as $\mathrm{Fe}, \mathrm{Mn}, \mathrm{Cu}$ and $\mathrm{Zn}$ were lower than $0.1 \mathrm{mg} \mathrm{kg}^{-1}$. The morality of the hydroxide was $0.002 \mathrm{M}$ with a $\mathrm{pH}$ of 10 . The $\mathrm{pH}$ higher than 7 was suitable as extractant for HA because the HA is soluble in base only ${ }^{[18]}$. A comparison between the yields of HA extracted from the composted SW using the hydroxide of the SW and that of the analytical grade were not statistically different.

The compost took about 60 days to mature. The compost temperature was below thermophilic stage. The compost temperature was in the mesophilic phase for eight weeks and gradually decreased to equal 
ambient temperature (Fig. 1). Maximum microbial diversity is in temperature of $35-40^{\circ} \mathrm{C}^{[19]}$. Low temperature in the compost involves the growth and respiration of micro-organisms such as aerobic mouldfungi and bacteria whereas high temperature is due to oxidation of cellulosic materials ${ }^{[20]}$.

The selected chemical characteristics of the compost in Table 2 suggest that it is mature with good quality. The $\mathrm{pH}$ of the compost increased from 4.58-7.39.

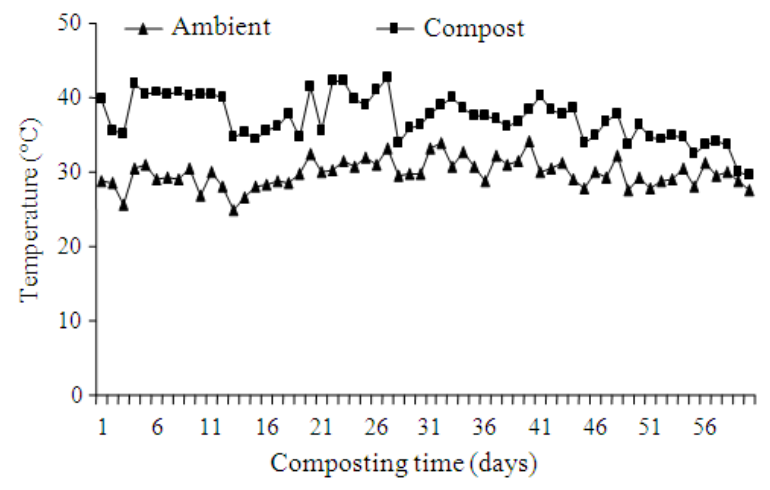

Fig. 1: Compost and ambient temperature during SW composting

Table 1: Selected elements of potassium and calcium hydroxide produced from ashed SW

\begin{tabular}{lc}
\hline Element & $\mathrm{KOH}\left(\mathrm{mg} \mathrm{kg}^{-1}\right)$ \\
\hline $\mathrm{K}$ & 29.51 \\
$\mathrm{Fe}$ & 0.02 \\
$\mathrm{Na}$ & 6.68 \\
$\mathrm{Ca}$ & 42.88 \\
$\mathrm{Mg}$ & 0.13 \\
$\mathrm{Mn}$ & 0.01 \\
$\mathrm{Cu}$ & 0.05 \\
$\mathrm{Zn}$ & Trace \\
\hline
\end{tabular}

Table 2: Comparison of the chemical characteristics of SW before and after composting

\begin{tabular}{lcc}
\hline & \multicolumn{1}{c}{ Initial } & Mature compost \\
\hline $\mathrm{pH}$ & $4.58 \pm 0.05$ & $7.39 \pm 0.05$ \\
$\mathrm{C} / \mathrm{N}$ ratio & $790.10 \pm 0.16$ & $27.30 \pm 0.39$ \\
$\mathrm{C} / \mathrm{P}$ ratio & $4485.42 \pm 318.7$ & $57.80 \pm 2.61$ \\
Ash $(\%)$ & $4.53 \pm 0.03$ & $20.93 \pm 1.76$ \\
Organic matter $(\%)$ & $95.50 \pm 0.03$ & $79.10 \pm 1.76$ \\
$\mathrm{CEC}\left(\mathrm{cmol} \mathrm{kg}^{-1}\right)$ & $14.90 \pm 2.14$ & $238.80 \pm 20.7$ \\
Humic acids $(\%)$ & $0.02 \pm 0.00$ & $1.15 \pm 0.21$ \\
\hline
\end{tabular}

\pm SE: Standard Error

Table 3: Chemical characteristics of humic acid of composted SW

\begin{tabular}{lcl}
\hline Variable & Range obtained & Standard range ${ }^{[18]}$ \\
\hline $\mathrm{E}_{4} / \mathrm{E}_{6}$ & 8.58 & $7-8$ \\
Carbon $(\mathrm{C} \%)$ & 56.80 & $56-62$ \\
Carboxylic $\left(\mathrm{cmol} \mathrm{kg}^{-1}\right)$ & 300.00 & $240-540$ \\
Phenolic $\left(\mathrm{cmol} \mathrm{kg}^{-1}\right)$ & 200.00 & $150-440$ \\
Total acidity $\left(\mathrm{cmol} \mathrm{kg}^{-1}\right)$ & 500.00 & $500-700$ \\
\hline
\end{tabular}

The $\mathrm{C} / \mathrm{N}$ ratio decreased from 790.1-27.3. The $\mathrm{C} / \mathrm{P}$ ratio also decreased from 4485.42-57.82. The ash content increased from 4.53-20.93\% suggesting mineralization of organic matter ${ }^{[21]}$ which indicates the decrease of organic matter in the compost. The Cation Exchange Capacity (CEC) also increased from 14.9-238.86 $\mathrm{cmol} \mathrm{kg}^{-1}$. The HA also increased from $0.02-1.15 \%$.

The chemical characteristics of the HA of composted SW are shown in Table 3. The values of the chemical characteristics of HA from composted SW were in the standard range reported by $\operatorname{Tan}^{[18]}$.

\section{DISCUSSION}

The high Ca was because sago is known to be high in this element compared to others. According to Haska $^{[2]}$, SW has low content of minerals and this may have contributed to the low soluble minerals in the hydroxide. Eventhough the concentration of the hydroxide produced from the SW was low, it was good for isolation of HA as high concentration of extractant affects the chemical structure of $\mathrm{HA}^{[12]}$. In terms of the quality of the extracted $\mathrm{HA}$, very weak $\mathrm{NaOH}$ or $\mathrm{KOH}$ solution of 0.001 to $0.01 \mathrm{M}$ is considered better than 0.1 $\mathrm{M}^{[18]}$. Besides using this hydroxide to extract the HA, it also can be used as liquid fertilizer for fertigation.

The high initial $\mathrm{C} / \mathrm{N}$ ratio (>700) of $\mathrm{SW}$ could be one of the factors for the slow rate of decomposition and low compost temperature. The SW itself has high content of starch which is more than $60 \%{ }^{[5,6,22]}$ and may have enhanced fungal growth particularly in the presence of $10 \%$ chicken feed, $5 \%$ of chicken dung slurry and $5 \%$ of molasses. Cayuela et al. ${ }^{[23]}$ reported that fungi have the ability to produce enzymes that are able to degrade lignin. The ability of fungal to degrade organic matter has been attributed to the reduction of easily degradable organic compounds and the subsequent decrease in bacteria ${ }^{[24]}$ which may be the reason why the compost did not achieved the thermophilic stage. Thermophilic stage is important for the sanitization of the compost so that it can be safely applied into the soil.

The $\mathrm{pH}$ of the compost increased from acidic to neutral due to degradation of acid-type compounds like carboxylic and phenolic groups or mineralization of compounds such as protein, amino acids and peptides to ammonia $^{[25,26]}$. The $\mathrm{C} / \mathrm{N}$ and $\mathrm{C} / \mathrm{P}$ ratios decreased due to mineralization. The decreased in organic matter content was caused by mineralization and humification ${ }^{[26]}$ resulting in the increase of ash content and HA. The increase in CEC suggests high amount of available minerals in the compost. Available minerals are very essential for the plant uptake. The HA existence 
indicated that the humification process occurred and this relates to the stability of the compost ${ }^{[27]}$.

The $\mathrm{E}_{4} / \mathrm{E}_{6}$ of the HA of the composted SW was 8.58. According to $\mathrm{Tan}^{[18]}$, ratio of $7-8$ or higher indicates the presence of HA with low molecular weight. High $\mathrm{E}_{4} / \mathrm{E}_{6}$ ratio reflects a low degree of aromatic condensation and presence of a relatively large proportion of alipathic structure indeed ${ }^{[28]}$. HA from compost showed a lower degree of aromatization than soil ${ }^{[29]}$. The carbon content of the HA of composted SW was in the range of the standard value. Total acidity, carboxyl-COOH, phenolic-OH content in soil HA were in the ranges of 500-700, 240-540 and $150-440 \mathrm{cmol} \mathrm{kg}^{-1}$ respectively as reported by $\operatorname{Tan}^{[18]}$. The values of carboxyl-COOH, phenolic-OH and total acidity of HA of SW were in the standard range (Table 3).

\section{CONCLUSION}

Potassium and calcium hydroxide, compost and HA can be produced from sago waste. Low morality of the hydroxide is able to produce good quality of HA from composted sago waste. The HA can be reconstituted with $\mathrm{K}$ and $\mathrm{Ca}$ from potassium and calcium hydroxide to produce $\mathrm{K}-\mathrm{Ca}$-humate and this needs to be investigated as a form of organic based fertilizer.

\section{ACKNOWLEDGEMENT}

This study was supported by a Fund of Ministry of Agriculture and Agro-based Industry Malaysia entitled "Utilization of sago waste in animal production". The authors acknowledge the assistance of the staffs of University Putra Malaysia, Bintulu Sarawak Campus, Malaysia.

\section{REFERENCES}

1. Wang, W.J., A.D. Powell and C.G. Oates 1996. Sago starch as a biomass source: Raw sago starch hydrolysis by commercial enzymes. Bioresour. Technol., 55: 55-61.

2. Haska, N., 2002. The utilization of the fibrous residue of sago palm as a substrate for the cultivation of edible mushrooms. New Front Sago Palm Stud., pp: 133-140. http://sciencelinks.jp/jeast/article/200407/000020040704A0199243.php
3. Oates, C. and A. Hicks, 2002. Sago starch production in Asia and the pacific-problems and prospects. Proceedings of the International Symposium on New Frontiers of Sago Palm Studies, Oct. 15-17, Tsubuka International Congress Center, Universal Academy Press, Inc., Tokyo, Japan, pp: 27-36. http://sciencelinks.jp/jeast/article/200407/000020040704A0199230.php

4. Cecil, J., 2002. The development of technology for the extraction of sago. Proceedings of the International Symposium on New Frontiers of Sago Palm Studies, Oct. 15-17, Tsubuka International Congress Center, Universal Academy Press, Inc., Tokyo, Japan, pp: 83-91. http://sciencelinks.jp/jeast/article/200407/000020040704A0199237.php

5. Vikineswary, S., Y.L. Shim, J.J. Thambirajah and N. Blakebrough, 1994. Possible microbial utilization of sago processing wastes. Resour. Conservat. Recycl., 11: 289-296. http://cat.inist.fr/?aModele $=$ afficheN\&cpsidt $=4168$ 580 .

6. Singhal, R.S., J.F. Kennedy, M.G. Sajilata, A. Kaczmarek, C.J. Knill and P.F. Akmar, 2007. Industrial production, processing and utilization of sago palm-derived products. Carbohydrate Polym., 72: 1-20. DOI: 10.1016/j.carbpol.2007.07.043

7. Quek, S.Y., D.A.J. Wase and C.F. Forster, 1998. The use of sago waste for the sorption of lead and copper. Water S. A., 24: 251-256. http://cat.inist.fr/?aModele $=$ afficheN\&cpsidt $=2379$ 350 .

8. Cambardella, C.A., T.L. Richard and A. Russell, 2003. Compost mineralization in soil as a function of composting process conditions. Eur. J. Soil Biol., 39: 117-127. DOI: 10.1016/S11645563(03)00027-X

9. Ahmed, O.H., M.H.A. Husni, A.R. Anuar and M.M. Hanafi, 2003. Alternative means of recycling pineapple leaf residues. Fruits, 58: 53-60. DOI: 10.1051/fruits:2002036

10. Ros, M., S. Klammer, B. Knapp, K. Aichberger and H. Insam, 2006. Long-term effects of compost amendment of soil on functional and structural diversity and microbial activity. Soil Use Manage., 22: $\quad 209-218 . \quad$ DOI: $\quad 10.1111 / \mathrm{j} .1475-$ 2743.2006.00027.x

11. Brady, N.C. and R.R. Weil, 2002. The Nature and Properties of Soils. 13th Edn., Pearson Education, Inc., New Jersey, ISBN: 0130167630, pp: 515.

12. Stevenson, F.J., 1994. Humus Chemistry: Genesis, Composition, Reactions. 2nd Edn., John Wiley and Sons, New York, ISBN: 0471594741, pp: 36. 
13. Ahmed, O.H., M.H.A. Husni, A.R. Anuar, M.M. Hanafi and E.D.S. Angela 2004. A modify way of producing humic acid from pineapple leaves. J. Sustain. Agric., 25: 129-139. DOI: 10.1300/J064v25n01_10

14. Susilawati, K. and O.H. Ahmed, 2008. Simple method of purifying humic acids isolated from tropical hemists (peat soil). Am. J. Applied Sci., 5:1812-1815.

http://www.scipub.org/fulltext/ajas/ajas51218121815.pdf

15. Chefetz, B., P.H. Hatcher, Y. Hadar and Y. Chen, 1996. Chemical and biological characterization of organic matter during composting of municipal solid waste. J. Environ. Qual., 25: 776-785. http://jeq.scijournals.org/cgi/reprint/25/4/77617

16. Inbar, Y., Y. Chen and Y. Hadar, 1990. Humic substances formed during the composting of organic matter. Soil Sci. Soc. Am. J., 54: 1316-1323. http://soil.scijournals.org/cgi/content/abstract/54/5/ 1316

17. Campitelli, P. and S. Ceppi, 2008. Effects of composting technologies on the chemical and physicochemical properties of humic acids. Geoderma, 144: 325-333. DOI: 10.1016/j.geoderma.2007.12.003

18. Tan, K.H., 2003. Humic Matter in Soil and the Environment: Principles and Controversies. Marcel Dekker, Inc., New York, ISBN: 0-8247-4272-9, pp: 39.

19. Saludes, R.B., K. Iwabuchi, A. Kayanuma and T. Shiga, 2007. Composting of dairy cattle manure using a themophilic-mesophilic sequence. Biosyst. Eng., 98: 198-205. DOI: 10.1016/j. biosystemseng. 2007.07.003

20. Nelson, M.I., T.R. Marchant, G.C. Wake, E. Balakrishnan and X.D. Chen, 2007. Self-heating in compost piles due to biological effects. Chem. Eng., 62: 4612-4619. DOI: 10.1016/j. ces.2007.05.018

21. Wang, P., C.M. Chang, M.E. Watson, W.A. Dick, Y. Chen and H.A.J. Hoitink, 2004. Maturity indices for composted dairy and pig manures. Soil Biol. Biochem., 36: 767-776. DOI: 10.1016/j.soilbio.2003.12.012

22. Ozawa, T., T. Ueno, O. Negishi, S. Masaki and M. Amari, 2002. Fundamental research on the production of feed from sago residue after the extraction of starch. Proceedings of the International Symposium on New Frontiers of Sago Palm Studies, Oct. 15-17, Tsubuka International Congress Center, Universal Academy Press, Inc., Tokyo, Japan, pp: 321-324.
23. Cayuela, M.L., M.A. Sanchez-Monedero and A. Roig, 2006. Evaluation of two different aeration systems for composting two-phase olive mill wastes. Process Biochem., 41: 616-623. DOI: 10.1016/j. procbio.2005.08.007

24. Lazcano, C., M. Gómez-Brandón and J. Domínguez, 2008. Comparison of the effectiveness of composting and vermicomposting for the biological stabilization of cattle manure. Chemosphere, 72: 1013-1019. DOI: 10.1016/j. chemosphere. 2008.04.016

25. Gil, M.V., M.T. Carballo and L.F. Calvo, 2008. Fertilization of maize with compost from cattle manure supplemented with additional mineral nutrients. Waste Manage., 28: 1432-1440. http://cat.inist.fr/?aModele $=$ afficheN\&cpsidt $=2041$ 0625

26. Bustamante, M.A., C. Paredes, F.C. Marhuenda-Egea, A. Pérez-Espinosa, M.P. Bernal and R. Moral, 2008. Co-composting of distillery wastes with animal manures: Carbon and nitrogen transformations in the evaluation of compost stability. Chemosphere, 72: 551-557. DOI: 10.1016/j.chemosphere.2008.03.030

27. Tomati, U., E. Galli, F. Fiorella and L. Pasetti, 1996. Fertilizers from composting of olive-mill wastewaters. Int. Biodeteriorat. Biodegradat., 1196: 155-162.

28. Campitelli, P.A., M.I. Velasco and S.B. Ceppi, 2006. Chemical and physicochemical characteristics of humic acids extracted from compost, soil and amended soil. Talanta, 69: 1234-1239. DOI: 10.1016/j. talanta. 2005.12.048

29. Wei, Z., B. Xi, Y. Zhao, S. Wang, H. Liu and Y. Jiang, 2007. Effect of inoculating microbes in municipal solid waste composting on characteristics of humic acid. Chemosphere, 68: 368-374. DOI: 10.1016/j. chemosphere. 2006.12.067 